\title{
QUANDO TODOS SUMIRAM: AS CONDIÇÕES DE ESTAR SÓ EM SOZINHO NO DESERTO EXTREMO, DE LUIZ BRÁS
}

Ricardo CELESTINO ${ }^{1}$

Diana NAVAS 2

\section{CONSIDERAÇÕES INICIAIS}

A literatura de ficção científica produzida no Brasil nas últimas duas décadas passa por uma crise paradoxal. De um lado, há uma força constante por parte da crítica especializada que generaliza o valor estético das obras, colocando-as como literaturas provenientes de um gênero menor, de valor inferior às costumeiramente estudadas e projetadas no mainstream. Por outro lado, as iniciativas de novas editoras, de selos editoriais e coletivos literários direcionam identidades diversas para um arcabouço de obras que levam à exaustação o trabalho de categorização e catalogação por parte do especialista com boa vontade. Tanto uma questão quanto outra parece dar-nos fôlego para uma empreitada produtiva nos estudos do discurso.

Dado o bom momento editorial da literatura de ficção científica produzida no século XXI e a iniciativa localizada em poucos programas de pós-graduação na dedicação em estudar profundamente estas obras, compreendemos ser produtivo tomar os discursos provenientes de obras da Literatura de Ficção Científica como amostras de pesquisa. Dessa maneira, temos como tema desse capítulo o estudo das condições de consolidação de um quadro hermenêutico para a análise de discursos provenientes de obras literárias da literatura de ficção científica. Para tanto, selecionamos arcabouços teóricos de campos distintos do estudo da linguagem e das ciências humanas.

Em um primeiro momento, apresentamos as condições de produção dos discursos literários de ficção científica, para posteriormente destacarmos os estudos de Maingueneau (2014) acerca do quadro hermenêutico. O autor observa que o discurso literário faz parte do arcabouço de discursos constituintes e propõe a

1 E-mail: ricardo.celestino2003@gmail.com

2 E-mail: diana.navas@hotmail.com 
definição de um quadro hermenêutico enunciativo-discursivo que reflete sobre as negociações de sentido entre enunciador e co-enunciador em um discurso, cujas regras são construídas na dialética da própria prática enunciativo-discursiva e das condições sócio-histórico culturais de produção da literatura de ficção científica.

Em seguida, destacamos os estudos de Bernardo (2010) e Navas (2009) acerca da metaficção. Categoria proveniente da Crítica Literária, a metaficção interessa-se por romances da pós-modernidade que refletem implícita ou explicitamente sobre o processo de construção da própria ficção ao longo da narrativa ficcional. São obras que inauguram, de alguma maneira, uma relação de participação ativa do co-enunciador na construção e negociação de sentidos com os discursos, a partir de um abismo de dois ou mais mundos ficcionais em uma mesma obra literária.

Por fim, selecionamos, como objeto de pesquisa, os discursos que problematizam a condição de estar só da obra Sozinho no deserto extremo, de Luiz Brás. A solidão da personagem-protagonista proporciona, ao leitor, a construção de sentido do texto literário sob pelo menos três planos ficcionais: o mundo povoado de Davi, personagem central da obra, o novo Davi, agora solitário, em busca de respostas e sobrevivência na solidão de um mundo onde todos desapareceram e somente ele continua ali e, por fim, o mundo do co-enunciador que participa ativamente na construção dos efeitos de sentido de estar só ao longo da enunciação. Para categorizarmos a condição de estar só, selecionamos o arcabouço teórico da Psicologia Clínica, principalmente nos estudos de Winnicott (1998), que categoriza a solidão nas fases de amadurecimento emocional do sujeito em duas etapas: a solidão essencial e a dependência absoluta.

\section{A LITERATURA DE FICÇÃO CIENTÍFICA NO SÉCULO XXI}

Compreendemos as condições sócio-histórico-culturais de produção como os direcionamentos que nos possibilitam construir os efeitos de sentido possíveis do discurso em análise. Para esta pesquisa, propomos apresentar, em um primeiro momento, as conjunturas inerentes à compreensão dos discursos literários de ficção científica no século XXI, uma vez que consideramos a obra Sozinho no deserto extremo, de Luiz Brás, pertencente a este gênero literário.

A condição de ficção científica implica um saber científico tratado como especulação ficcional em enunciados literários. Roberts (2018) observa a FC como construto verbal cujas condições necessárias e suficientes são a presença e interação de distanciamento e cognição, e cujo dispositivo principal é uma moldura imaginativa alternativa ao ambiente empírico do autor. A premissa ficcional, dessa maneira, coloca em foco a diferença entre o mundo que o leitor habita e o 
mundo ficcional da FC, denominado como novum. O novum pode ser uma máquina do tempo, um dispositivo mais rápido que a luz ou algo conceitual como uma nova versão de mundo familiar ao nosso, mas desértico.

A FC reflete de maneira crítica, segundo Roberts (2018), sobre as revoluções culturais, científicas, tecnológicas e em nosso caso as mudanças epistêmicas da psiquê humana em condições sociais e culturais traumáticas. Presentes tanto na obra como um todo ou, de maneira localizada, como empreendimento estético de alguns enunciados localizados, a FC implica o emprego de recursos enunciativo-discursivos marcados por estratégias metafóricas e táticas metonímicas de tratar essas mudanças, bem como a colocação, em primeiro plano, de ícones e esquemas que estimulam a construção de efeitos de sentido dos valores de uma dada coletividade. Desta maneira, é condição cultural aos discursos literários de FC o engajamento semiótico e um conhecimento epistêmico profundo de uma certa postura científica tratada, afim de problematizá-la em ficção.

Roberts (2018) observa ainda que as novelas de FC do século XXI, diferente do que é desenvolvido em boa parte das franquias cinematográficas de Hollywood, tem apontado para uma alternativa temática distinta da vacuidade de um produto, em que velhos preconceitos ideológicos determinam tudo o que há no texto e no qual o texto em si reforça. Isto significa que o heroísmo individual, o potencial redentor da violência, o capitalismo por necessidade de consumo não são alternativas temáticas predominantes na FC. No Brasil, obras como Favelost, de Fausto Fawcett, as Águas Vivas Não Sabem de Si, de Aline Walek e, em nosso caso, Sozinho no deserto extremo, de Luiz Brás, condensam vozes da diversidade dentro do gênero, potencializando subjetividades complexas em pautas culturais e sociais caras à vida cotidiana brasileira.

Matangrano e Tavares (2018) compreendem que uma das características da ficção científica nacional é o insólito. No século XXI, ele se dá mediante a criação de mundos nas mais diversas potencialidades, não raro ocorrendo um hibridismo entre dois ou mais modos narrativos, com supremacia ora do científico, ora do fantástico. A ficção científica brasileira encontra, nos punks, nas distopias, no space opera novas formas de expressão, uma vez que os toma por categorizações que criam mundos, repensam o passado, criam possibilidades para o futuro. Descolam, dessa maneira, qualquer ligação com o nosso universo, recriando novas leis, nova geografia, nova história, novas religiões e mitologias, para depois retornar a nosso universo e ressignificar as nuances sócio-culturais refletidas.

Embora a FC tenha ganhado expressividade tímida ao longo dos anos nas pesquisas acadêmicas e nos grandes prêmios literários nacionais, Matangrano e Tavares (2018) chamam atenção para o bom momento editorial das obras que se enquadram nesse gênero. O surgimento e a consolidação de editoras como Devir, Aleph, Draco, Tarja, Terracota, Giz, especializadas em literatura de gênero, e 
ainda, selos específicos de grandes editoras para essa área, proporcionam a multiplicação de autores e autoras do gênero. Isso é convidativo para que a crítica passe a olhar para a FC com outros olhos, garimpando bons e maus textos do gênero com maior rigor. Ainda, vale destacar que a movimentação editorial tem estimulado a presença da inclusão e da diversidade, o protagonismo das minorias, que concentram, dentre outros temas, o folclore indígena, vide as obras de Daniel Munduruku, e o imaginário de matriz africana, em Fábio Kabral, por pontos de partida para o revisionismo do insólito nacional.

Mantagrano e Tavares (2018) apontam que o momento editorial satisfatório ainda não inibe o preconceito entorno das obras de FC e fantasia por grande parte da crítica especializada. A recorrência à tradição da escrita pulp pelos autores e autoras do gênero, marcando uma renúncia ao elitismo literário e ao hiper-realismo da alta literatura brasileira podem ser um dos desencadeadores desse olhar enviezado da academia sobre esses discursos literários. No entanto, os autores destacam o manifesto publicado no Jornal Rascunho, pelo autor Luiz Brás, o qual realiza um breve convite ao mainstream, termo que identifica a alta literatura, vencedora dos grandes prêmios literários e que encabeça os grandes contratos editoriais. $\mathrm{O}$ manifesto destaca que a FC tem propriedades de um gênero literário popular com uma força que, em diálogo com a alta literatura, poderia conduzir a Literatura Brasileira a direções diferentes e produtivas. Sob a perspectiva de que a alta literatura se encastela em problemáticas muito parecidas entre si, a FC pode ser uma alternativa para sacudir as certezas constituídas ao longo das décadas por esse tipo de discurso literário. Em contrapartida, a alta literatura também pode alterar os caminhos das águas dos discursos literários de FC, solapados pela fórmula de escrita pulp, tão atrativa aos leitores do gênero, mas já há muito utilizada ao longo das décadas de ouro de 1970 a 1990. Embora o convite esteja lançado, ainda há um longo caminho até que a literatura de FC brasileira divida as estantes virtuais e físicas das grandes livrarias, bem como os primeiros lugares nos grandes prêmios literários, ao lado da alta literatura.

\section{O QUADRO HERMENÊUTICO}

Consideramos que a construção dos efeitos de sentido para os discursos selecionados para esta pesquisa está subordinada ao estabelecimento de um quadro hermenêutico enunciativo-discursivo. Maingueneau (2014) contribui para essa categorização, ao observar que a literatura mantém uma dupla relação com o interdiscurso: as obras se alimentam de outros textos mediante diferentes procedimentos e reempregam, interpretam e citam esses textos nos enunciados. $\mathrm{O}$ texto literário não é um enunciado autossuficiente, mas um enunciado a ser tomado em um quadro hermenêutico. Ao propomos um quadro hermenêutico sob as ma- 
trizes da perspectiva enunciativo-discursiva, buscamos ofertar direcionamentos para a prática da construção dos efeitos de sentido na relação enunciador-co-enunciador em um espaço e em um tempo específicos.

Maingueneau (2014), observa que há um debate entre aqueles que privilegiam a legitimação conferida pelo domínio das técnicas e aos que privilegiam a experiência pessoal, para a escolha do quadro hermenêutico que irá direcionar a construção de sentidos em um discurso literário. Dos tecnicistas, os quais nos interessam para este estudo, o texto literário digno de interesse é aquele que o enunciador transcende a mensagem enviada. Há, no discurso literário, uma mensagem oculta presente, desencadeada por uma exegese proposta pelo crítico/analista: existência de técnicas, relação privilegiada do leitor com a fonte, dentre outros.

O texto inscrito em um quadro hermenêutico está prescrito a um estatuto pragmático. Maingueneau (2014) compreende este estatuto por um modo de existência no interdiscurso. Envolve um esforço de instituição e preservação do significante em sua autenticidade. O discurso literário não pode deixar de ser enigmático, de revelar mensagens importantes para a coletividade. Quanto mais interpretado o texto, mais enigmático ele é, uma vez que mais quadros hermenêuticos determinam mais vias de leitura e construção de efeitos de sentidos.

Cada nova leitura, para Maingueneau (2014), torna mais complexo o labirinto de interpretações, ao encerrar o texto em seu próprio labirinto. Cabe ao analista ou crítico enfraquecer o grau em que o texto é enigmático, a partir do quadro hermenêutico o qual se apoia. No entanto, críticos e analistas não esgotam a hermeneia, a palavra essencial que a fonte reserva. Por fazer parte dos discursos constituintes, o discurso literário não tem um autor no sentido usual, mas uma instância sem rosto que trafega entre o sujeito empírico, o sujeito social e o enunciador da obra. Trata-se de uma posição que não é totalmente ocupada, o que proporciona a pluralidade de interpretações. Ao despossuir a obra de um autor, o crítico ou o analista assumem essa autoridade, também de maneira limítrofe.

Inscrita em um quadro hermenêutico, a obra, para Maingueneau (2014), diz algo distinto do que ela diz. Toda clareza que ela concentra, dessa forma, é enganosa. Os textos exigem que o destinatário derive sentidos ocultos, descobrindo o ponto onde a clareza se obscurece, a fim de apontar o enigma que se espera que encerre. O quadro hermenêutico garante que as transgressões das leis do discurso sejam apenas aparentes e que as exigências das comunicações sejam respeitadas. Define, assim, os contornos da natureza do sentido oculto de um discurso literário. $\mathrm{O}$ crítico ou o analista legitimam-se a cada interpretação bem sucedida e validada pelo meio, relegitimando o quadro hermenêutico o qual estão filiados. O crítico e o analista mostram que são competentes e que o texto é enigmático. 
Ainda, que se trata de um discurso constituinte, fundador de subjetividades oblíquas.

No quadro hermenêutico, Maingueneau (2014) destaca, ainda, que um texto literário beneficia-se de uma hiperproteção. Tudo que é enunciado tem liberdades normativas do discurso sem arranhar seu prestígio. Os intercâmbios verbais são regidos por normas, que postulam máximas conversacionais sujeitas a um princípio de cooperação. O processo de comunicação da obra literária é semelhante a um ato de enunciação sujeito à normas de interação verbal. Isso afasta a lógica de que a obra detém um mundo autárquico, indiferente às considerações de sua recepção.

A obra literária se funde em máximas conversacionais, sem se encerrar totalmente nelas. Quem as oferece é o quadro hermenêutico que a obra se inscreve, em nosso caso, a metaficção em um discurso literário de ficção científica. Simultaneamente, Maingueneau (2014) compreende que o artista é o único legislador de seu universo. Se o crítico ou analista percebem numa obra o que julgam ser um erro, ou defeito, um fragmento fora de prumo, talvez possa ter sido em virtude de lançar mão de normas que não as que estabeleceu o artista para si. A transgressão de normas é a marca de que é preciso inferir um sentido oculto, uma reflexão sobre a transgressão.

Por fim, Maingueneau (2014) observa que enquanto analistas ou críticos literários, nos deparamos com uma diversidade de procedimentos de análise. $\mathrm{O}$ autor de uma obra literária pode confiar no quadro hermenêutico, uma vez que o texto está hiperprotegido, detém expectativas de um leitor-modelo, para que ele faça um esforço de extrair implícitos necessários para conciliar as transgressões das normas com o postulado de que há uma cooperação mútua entre os envolvidos na enunciação. Contudo, o universo estético o qual o autor participa não postula autonomia absoluta às obras literárias. O empreendimento da criação literária prescinde, assim, de justificativas constantes do percurso utilizado pelo artista, quer por ele mesmo, quer por críticos, fãs ou analistas.

Tomar a palavra em um discurso literário pressupõe uma incursão territorial, um cumprimento de papeis, onde o destinatário pode, constantemente, sentir sua face negativa ameaçada, exigindo reparações. O autor é performático, segundo Maingueneau (2014), o que implica uma redução hermenêutica na prática enunciativa. Chama-se redução hermenêutica a anulação de uma transgressão pela derivação de um implícito fundado no quadro hermenêutico. Podemos distinguir as reduções ditas e as implicadas pragmaticamente.

As reduções implicadas pragmaticamente, para Maingueneau (2014), são aquelas desencadeadas pelo fato de o texto se vincular a um quadro hermenêutico. As transgressões não são acompanhadas de enunciados que garantam o per- 
tencimento a esse quadro. As reduções ditas, por sua vez, encontram comentários que tem a função de assegurar que a transgressão está a serviço de um sentido mais elevado, em conformidade com o quadro hermenêutico. O grau de explicitação é variável e pode ser o conjunto da obra que procede redução hermenêutica. $\mathrm{O}$ universo criado legitima as aparentes transgressões que a tornam possível.

Em linhas gerais, Maingueneau (2014) observa que se o leitor não fecha um romance, isso se deve ao fato de ele postular a validade do quadro hermenêutico, de presumir que partilha um saber mútuo sobre a natureza do discurso literário, aceitando as reduções hermenêuticas. A obra transmite, assim, uma hermeneia. Os implícitos construídos por redução hermenêutica auxiliam nesse processo, pois orientam o co-enunciador para um certo registro. O leitor, por sua vez, deve presumir tratar de interpretações que buscam um sentido último de existência ou de uma tomada de posição estética. O processo é favorecido pelo conhecimento de uma certa doxa sobre o quadro hermenêutico e o autor.

Maingueneau (2014) acredita que o conhecimento de quadros hermenêuticos possibilita um leitor mais crítico. O leitor menos hábil é aquele que, diante de regras novas apresentadas pelo enunciador, desencadeia construções de sentido circulares. A leitura exige construção de implícitos, que longe de ser inferidos no processo de leitura de uma obra, estão na verdade presentes na memória do leitor. Este os ativa, realizando interpretações profundas ou ilustrativas do discurso literário.

\section{A METAFICÇÃO}

Compreendemos que o discurso literário selecionado pode ser tomado por um olhar metaficcional. Bernardo (2010) observa a metaficção como fenômeno estético autorreferente através do qual a ficção duplica-se por dentro, falando de si mesma ou contentando a si mesma. Considerando que o mundo contemporâneo se transforma com grande rapidez, as técnicas tradicionais da narrativa, que tratam a obra como um heterocosmo dissociado de toda a realidade do leitor, são incapazes de integrar a pluralidade das relações humanas. A consequência, é um mal-estar que nos direciona a uma crise consciente do descontrole em ordenar todas as informações que constituem a subjetividade da experiência ficcional.

A metaficção, para Navas (2009, p.88), não é algo novo, mas:

uma tentativa de encontrar um modo estético de lidar com as novas experiências de vida do homem moderno, experiências estas que revelam desordenadas por um poder comunal ou transcendente, a que apenas a arte, de forma não problemática, pode conferir uma certa ordem consoladora. 
Navas (2009) destaca por uma das condições da metaficção a presença de enunciados que concentram um conjunto de vozes que se cruzam, entrecortados, em fragmentos de diálogos, monólogos incompletos e frases inacabadas, constituindo um mosaico memorial que se impõe como único fio condutor de uma história. A partir da retomada da concepção de Barthes (2002, p.26), atribui a certos discursos metaficcionais a condição de texto de gozo, que

em oposição ao de prazer, coloca um estado de perda, que desconforta, faz vacilar os alicerces históricos, culturais, psicológicos do leitor, a consistência de seus gostos, de seus valores, de suas lembranças, põe em crise sua relação com a linguagem.

Em textos metaficcionais, a linguagem não se reduz a um ofício com a palavra, apenas no nível do significante, mas a um processo de construção de efeitos de sentido que se inicia no plano do significante, desenvolvido por um autor, e estende-se à uma reestruturação semântica por parte de quem o lê. Hutcheon (1984) afirma, nesse sentido, que a metaficção é a ficção sobre a ficção, o que significa uma dinâmica de a ficção incluir dentro de si própria um comentário ou pistas sobre sua própria narrativa ou identidade linguística.

A linguagem é representacional, para Hutcheon (1984), em toda ficção. No entanto, na metaficção a separação de um mundo ficcional a outro, ou seja, a relação do leitor com o heterocosmo que o distancia daquele criado pelo texto literário, não está claro. Enquanto o leitor toma contato com os textos literários, ele vive em um mundo que é forçado a considerar como ficcional. Paradoxalmente, contudo, os enunciados presentes naquele texto exigem a participação direta do leitor, seu envolvimento intelectual, imaginativo e afetivo na co-criação de sentidos. O paradoxo do leitor implica, na metaficção, uma atração bilateral que caracteriza o texto em uma relação narcísica: ao mesmo tempo que ele é auto-reflexivo, ele também está focado no exterior, orientado ao leitor.

Navas (2009) destaca que nos textos metaficcionais, o escritor chama a atenção do leitor para a atividade escritural, seja através de um evento dentro do próprio romance, seja exibindo seus sistemas ficcionais e linguísticos ao leitor. Dessa maneira, o processo de fazer a narrativa torna-se diretamente compartilhado, assumindo o leitor a posição de coautor, construindo os efeitos de sentido do texto. A metaficção implica, então, um processo de desfamiliarização das relações com o significante por parte dos envolvidos no texto. O leitor é atraído aos procedimentos inconscientes da construção narrativa e convidado a atuar ativamente neles para a construção dos efeitos de sentido, o que implica novas exigências e atenção ativa para o ato de leitura. 
Hutcheon (1984) considera a existência de dois tipos de metaficção: a explicitamente narcisista; e a implicitamente narcisista. A primeira pressupõe textos que revelam sua autoconsciência em tematizações explícitas, quer por meio de alegorias de uma diegese ou pela identidade linguística. A segunda, por sua vez, parte de um processo internalizado e efetivado na linguagem, sendo auto-reflexivo, porém não necessariamente autoconsciente. Em outras palavras, textos narcisistas explicitamente diegéticos explicitam a consciência de sua condição de artefatos literários, dos processos de sua narrativa e criação do mundo, e da presença necessária do leitor. Outros textos, por sua vez, podem tematizar o poder subjugado e a potência das palavras, sua capacidade de criar um mundo mais real do que o empírico de nossa experiência.

Bernardo (2010) destaca em Dom Quixote, de Cervantes, uma obra metaficcional produtiva. O romance de cavalaria convida o leitor a fazer parte de um jogo, onde o cavaleiro justifica todas as derrotas frente à realidade, atribuindo-as a feitos malvados dos inimigos que encontra em suas andanças. No episódio $O$ mestre das marionetes, ele atribui aos encantadores o próprio delírio, justificando assim o seu movimento errático entre a ficção e a realidade. Os supostos encantadores do fidalgo parecem maus, mas na verdade eles tem a função de garantir a coexistência das diferentes ficções e das diferentes realidades que se entrecruzam na narrativa.

O que se reconhece por realidade, para Bernardo (2010), não é também mais do que um determinado discurso sobre a realidade. Não se representa a realidade para repeti-la ou duplicá-la, mas para dobrá-la e recriá-la. Dessa maneira, a metáfora trai nossas concepções de realidade, monstrando-as como efeitos de discursos. O real, por sua vez, não deixa de ser uma construção sintática que, tendo sua verossimilhança abalada, é ponto de partida para a sedimentação de diversos níveis de ficção. Na metaficção, essas fatias ficcionais emergem à semelhança de babushkas dentro de babushkas. Nesse sentido, tudo no universo metaficcional é de índole caleidoscópica e nada melhor que Dom Quixote para ilustrar essa condição: objetos inertes, estalagens e animais mostram capacidade de tomarem-se por moinhos de vento gigantes, exércitos de soldados, castelos e seres mágicos. Há, dessa maneira, uma mobilidade conjectural em temas do livro para temas da vida, da morte, do amor, dos valores, da justiça, dentre outros.

Por fim, podemos observar, a partir de Bernardo (2010), que a metaficção é produtiva enquanto quadro hermenêutico, pois categoriza a multiplicidade de perspectivas narrativas, adequadas à multiplicidade de facetas de um personagem de uma obra. Ora um herói, ora um palhaço, ora um sábio, ora um louco, ora um santo, ora um desequilibrado, Dom Quixote, com seus muitos livros contemplando muitas perspectivas, acaba por representar a tolerância na época em que a Espanha se mostra mais intolerante. Além de propor fatias ficcionais dentro da 
obra, também convida o leitor de sua época a uma ressignificação de sua realidade, tomando-a como parte da obra.

\section{A CONDIÇÃO DE ESTAR SÓ EM SOZINHO NO DESERTO EXTREMO, DE LUIZ BRÁS}

A amostra de nossa pesquisa consiste em discursos extraídos da obra Sozinho no deserto extremo, de Luiz Brás. Publicado em 2012, pela editora Prumo, a obra problematiza quais seriam as subjetividades de um sujeito da classe-média paulistana acordar em um determinado dia e descobrir que ele é o único sujeito vivo em todo o planeta. Todos desapareceram, exceto Davi. Publicitário bem-sucedido, acorda em um domingo e percebe que mulher, filhos, vizinhos, todos, evaporaram. Brás problematiza, a partir dessa premissa, as estratégias do sujeito para manter a sanidade mental e a própria noção de individualidade em um mundo despovoado, sem ninguém em quem se espelhar. Ainda, cria situações das quais dificilmente problematizamos como: a sobrevivência sem serviços básicos de alimentação, transporte e saúde; a vida diante da solidão concreta.

Consideramos os discursos literários extraídos da obra por ficção científica. O saber científico tratado por especulação ficcional é a solidão ou a sensação de sentir-se só, objeto de estudos da Psicologia Clínica, dos quais destacamos Batista (2017) que recupera Winnicott (1968) para refletir acerca da capacidade de estar só. Dessa maneira, dividimos nossa análise em dois momentos: inicialmente, apresentamos as condições da capacidade de estar só na perspectiva de Batista (2017), tomando-as por formações discursivas necessárias para a negociação de efeitos de sentido no discurso literário selecionado. Em seguida, analisamos como as formações discursivas da Psicologia Clínica constituem o novum que possibilita tomarmos os discursos literários em análise em um quadro hermenêutico metaficcional.

\section{A capacidade de estar só}

Batista (2017) compreende que a natureza humana não se reduz às condições biológicas para o amadurecimento enquanto espécie. Além de ser um corpo biológico, permeia na constituição humana experiências emocionais que ofertam sentidos pessoais atribuídas à imaginação. O meio ambiente é um dos facilitadores dessa dinâmica de crescimento processual do indivíduo enquanto ser humano. Embora o ser humano seja dotado de genes que determinam padrões sociais e biológicos, nada se realiza no crescimento emocional, sem o desenvolvimento do sujeito esteja em conjunção à provisão ambiental. 
A participação do ambiente é decisiva e constitutiva para o crescimento emocional do indivíduo. Para o autor, as tendências herdadas biologicamente fornecem o dinamismo desse processo, no entanto, a singularidade de cada indivíduo estabelece relação dialética com o ambiente e a produção imaginária. O amadurecimento emocional se dá em contato com o ambiente facilitador que possibilita a incorporação das experiências do indivíduo provenientes de sua criatividade. Dessa forma, é necessário que ao longo da vida o sujeito combine os fatores herdados e os fatores ambientais, que só farão parte da personalidade individual caso o sujeito se aproprie deles por meio da experiência. Distúrbios e outras patologias surgem, comumente, derivados de problemas de falta de adaptabilidade do ambiente ao sujeito, que não encontra formas de orquestrar suas características singulares com a complexidade da sociedade.

Batista (2017) compreende que a provisão ambiental tem papel relevante no processo de amadurecimento emocional, a ponto de nos oferecer bases teóricas para a compreensão das condições de estar só. A solidão surge de forma embrionária em nossos primeiros instantes de vida consciente, na fase intrauterina. Prossegue nos estágios primitivos de dependência absoluta, se mantém pela dependência relativa e, por fim, na independência relativa. $\mathrm{O}$ autor descreve, então, cada um desses estágios, que, para este capítulo, nos atentamos em destacar apenas os dois primeiros: a dependência absoluta e a dependência relativa.

Acerca da dependência absoluta, Batista (2017) chama-nos atenção para a solidão essencial. O pesquisador compreende a solidão essencial como o estado do ser ao emergir do estado de não-ser. Trata-se de uma consciência incipiente da continuidade do ser e do existir no tempo, anterior à capacidade do indivíduo racionalizar o mundo que vive. O sujeito emerge, dessa maneira, não do inorgânico, mas da solidão essencial, e a partir dela buscará integração em uma identidade unitária.

Batista (2017) destaca, a partir de Winnicott (1998), que todo indivíduo quando nasce é capaz de perceber o ambiente como algo nem externo nem interno a si. Esse desconhecimento paradoxal implica dependência absoluta do ambiente, onde a continuidade do ato de existir enquanto indivíduo não seja perturbada por intrusões do meio. Trata-se de uma raiz precoce do desenvolvimento emocional, que requer uma dependência maior do ambiente. O indivíduo humano não é ainda uma unidade, pois ele ainda não está em condições de perceber o ambiente. Também não há um self individual que discrimine o eu de um não eu.

A solidão essencial só pode existir em condições de dependência máxima. Isso se dá pois, para Batista (2017), ela mantém a tensão entre o não-ser e o ser. Isso quer dizer que os direcionamentos ambientais disponíveis são responsáveis por tornar possível a integração do sujeito com o meio e a sua constituição existencial. O sujeito não pode existir sozinho, uma vez que sua própria natureza lhe 
impõe necessidades que não podem ser satisfeitas por ele próprio. Ele necessita de um outro que cuide, sustente e proteja sua constituição e sua identidade.

Batista (2017) defende que o fator primordial para o desenvolvimento humano é o continuar a ser. Fortes intrusões ambientais traumatizam, uma vez que interrompem a continuidade do ser, obrigando-o a reagir a tais intrusões.

A solidão essencial nos permite identificar na não comunicação, um aspecto central da natureza humana: o ser isolado. Cada indivíduo é isolado permanentemente sem se comunicar, desconhecido, em uma realidade nunca encontrada. Isso conduz o autor a teorizar sobre o núcleo do si-mesmo, incomunicável, oculto e de onde emana os gestos espontâneos e a criatividade originária de toda a vida. O sujeito experimenta sua criatividade original e o gesto espontâneo quando não reconhece o ambiente como tal, ou como os demais sujeitos já racionalizados reconheceriam.

O segundo ponto que destacamos nos estudos realizados por Batista (2017) é a dependência absoluta. Este estágio implica o momento mais primitivo da vida do sujeito, em que ele vive em situação de dependência absoluta da mãe até o período de passagem para a dependência relativa. Após a concepção, há um primeiro despertar que desenvolve um estado de ser, uma consciência incipiente da continuidade do ser e do existir no tempo. O bebê chegará a um estado de ser e necessitará continuar a ser, onde derivarão todas as demais necessidades do indivíduo até a morte. Ser e continuar a ser constitui o substrato das tarefas do amadurecimento pessoal e de suas conquistas. A presença das figuras cuidadoras e a busca de satisfação das necessidades instituais garantem ao sujeito a possibilidade de continuar a ser, estabelecendo o si-mesmo o sentimento de ser-real-autêntico neste mundo.

A espontaneidade e a reatividade são essenciais para o processo maturacional da emoção. Para Batista (2017), o bebê é como uma bolha, uma vez que se a pressão externa está adaptada à pressão interna, a bolha continua existindo. Por sua vez, quando a pressão exterior é maior ou menor que a interior, a bolha se modificará como reação a uma mudança no ambiente. Isso significa, no caso do ser-humano, uma ameaça do ser, fruto da reação à intrusão, o que implica quadros de enfermidade emocional.

Após o estágio de nascimento, simbolizado pela intrusão, o bebê necessita recuperar a descontinuidade inerente ao processo de nascimento para retornar ao sentimento de continuidade de ser. Isso o conduz a um estado de quietude. Em seguida, é necessário a promoção de experiências que implique o começo de contato com a realidade e o desenvolvimento de um si-mesmo que integrará progressivamente o indivíduo a uma unidade. Batista (2017) compreende que a qualidade do contato humano e a realidade da experiência serão significativas no âmbito do 
amadurecimento pessoal. O contato implica lançar mão de acordos que fundamentam as bases de um relacionamento humano. São nas interações que o sujeito consegue se relacionar com os objetos do mundo.

Sobre o processo de amadurecimento, Batista (2017) observa que para dar início a um sentido de real e poder habitar em um mundo real, o sujeito precisa ser introduzido na ordem do tempo e do espaço. O sujeito começa a ocupar espaços quando, munido de um corpo confortável com o meio, consegue dar concretude à presença, ter distância e proximidades, a delinear caráter transitório daquilo que envelhece e morre.

O sujeito encontra lugar de conforto e confiança no processo de amadurecimento, quando há um equilíbrio do meio externo em três etapas: na integração no espaço e no tempo favorecidos pela segurança ou através da sensação de segurança do ambiente; no cuidado físico, pelo manejo; na apresentação dos objetos. Os três fatores, para Batista (2017), permitem a continuidade do ser.

O sujeito é processualmente integrado, temporalizado, realizado, tornando-se capaz de reconhecer coisas e predizer acontecimentos. A tendência de integração do sujeito em uma unidade implica o reconhecimento desse mundo a partir de atos de criatividade originária, que também propicia o desenvolvimento emocional do indivíduo.

Batista (2017) observa que cada sujeito cria o mundo de novo e começa seu trabalho no mínimo tão cedo quanto o momento do seu nascimento. A criatividade originária implica a maneira como o indivíduo se relaciona com o sentido de realidade e, no evoluir maturacional, com os sentidos de realidade sem perder o contato com o seu mundo pessoal imaginativo. A criatividade é experimentada pelo indivíduo em formas cada vez mais complexas. O indivíduo cria o mundo, dotando-o de sentido pessoal. O mundo experienciado pelo sujeito é dotado de sentido pessoal pelo gatilho da criatividade originária. Nos primeiros instantes de ida, o sujeito identifica alguém que atenda às suas necessidades no momento que essas surgem, possibilitando a experiência da ilusão de onipotência.

A assistência invisível ao sujeito introduz a ele a ilusão de que ele cria o mundo que necessita e isso o faz experimentar a onipotência da ilusão. A ilusão é essencial para o sujeito encontrar significado pessoal no mundo em que vive. A onipotência, para Batista (2017), é aspecto essencial da dependência. O sujeito não tem conhecimento da sua existência e nem do mundo externo onde vive, porém, cria o objeto que encontra. A situação traumática se situa na condição de o sujeito, quando em necessidade, buscar assistência invisível e ela encontrar-se ausente. O gesto de desejo ficará no vazio, à espera de algo que vem. Isso resulta na interrupção da continuidade do ser. Encontra-se, na dependência absoluta, a matriz da capacidade em que a criança e o adulto saudável deixam o mundo momen- 
taneamente para descansar, a base da conquista posterior da capacidade de estar só na presença de alguém.

\section{Estar só no deserto extremo}

Nos discursos literários da obra Sozinho no deserto extremo, identificamos que há uma moldura imaginativa alternativa entorno do ambiente empírico do autor, construída ao longo da enunciação, na condição da personagem central da obra ser o único sujeito vivo em todo o planeta. A premissa coloca em foco diferenças e semelhanças entre o mundo que o co-enunciador habita e o mundo ficcional de Davi. Tal premissa é o embrião da ficção científica, que Roberts (2018) denomina o novum.

O enunciador estimula a construção de efeitos de sentido dos valores de uma coletividade pertencente à vida paulistana de classe média afetados por mudanças epistêmicas da psiquê de Davi, em virtude das condições culturais traumáticas de estar só. O co-enunciador potencializa os efeitos de sentido dos discursos presentes na obra e parte de um direcionamento acerca do conhecimento epistêmico do que é estar só, como podemos observar no recorte abaixo.

Recorte I (BRAS, 2012a, p.11)

Ele é apenas um homem sem qualidades visiveis. Nem jovem nem velho, nem inteligente nem obtuso. Pior, nem rico nem pobre. Ele é apenas um homem comum e desencantado, que já acreditou em muita bobagem ideológica - na civilização, na economia de mercado, na inteligência moral - e agora só acredita no fogo.

Ele já teve uma mulher. Também já teve filhos amados. Sessenta e tantos dias atrás sua vida era muito diferente. Sua filosofia era outra. Mais mundana, menos solitária.

Agora só o fogo interessa.

O fogo que ilumina. O fogo que purifica.

Ele é só um homem sem graça e sem carisma que se acha-me perdoe a expressão vulgar - um bruxo de desenho animado. Um aprendiz de feiticeiro. $O$ último da face da Terra.

No recorte I, podemos perceber que a seleção do quadro hermenêutico da metaficção nos auxilia a identificar as condições de estar só de Davi. Aquilo que conduz o co-enunciador a conhecer Davi, a partir da exposição do enunciador, 
são enunciados que concentram fragmentações de personalidade - um homem comum e desencantado, que já acreditou em muita bobagem ideológica - de faixa etária indeterminada - Nem jovem nem velho, - de estrutura familiar - Ele já teve uma mulher. Também já teve filhos amados. O enunciador estabelece uma relação de proximidade com o co-enunciador ao utilizar enunciados em segunda pessoa, como em me perdoe a expressão vulgar. O parênteses dado ao quadro cênico estabelecido, de apresentação do protagonista de uma ficção, funciona como um convite ao co-enunciador para entrar na história e participar dos processos de construção de sentido na condição de um coautor.

Ainda, podemos perceber que as adjetivações enunciadas constituem um mosaico memorial que convida o co-enunciador a refletir sobre duas ficções simultâneas: a vida de Davi antes de todos desaparecerem; a vida de Davi no momento que se dá a exposição do enunciador. Davi, na condição de único sujeito vivo no planeta, encontra-se em estado de perda, sensação esta que o co-enunciador pode tomar para si, compreendendo que os alicerces histórico-culturais, a consistência dos valores, das lembranças estão em crise neste novo mundo. Davi não é mais pai, não conta mais com nenhuma ideologia que o motive e, na condição de solitário, é um sujeito sem graça e sem carisma, comparado pelo enunciador, a um bruxo de desenho animado.

O enunciador compreende que o meio ambiente é um dos agentes responsáveis pelo processo de involução emocional de Davi. Não há crescimento emocional do personagem diante da condição de estar só. Em disjunção à provisão ambiental, Davi sente-se confuso em relação ao meio, já que não tem explicações objetivas para o desaparecimento de todas as pessoas. O insólito que confunde a cabeça de Davi, por sua vez, também confunde a cabeça do co-enunciador que constantemente pode arriscar palpites para o que aconteceu com toda a humanidade que simplesmente desapareceu e, ainda, compactuar com as angústias da personagem.

Ainda, como podemos observar nas reflexões de Winnicott (1968), a participação do ambiente é decisiva e constitutiva para o desenvolvimento emocional do indivíduo. No caso de Davi, o enunciador o toma como um sujeito que, por não encontrar respostas científicas ou objetivas para o que está acontecendo no mundo, recorre aos scripts da infância e deixa de ser pai de família, homem comum, de intelectualidade média, para assumir o papel de um bruxo de desenho animado que acredita no poder destrutivo do fogo. A singularidade de Davi, a capacidade de estabelecer as alternativas possíveis para sobreviver naquele ambiente e lidar com a condição de estar só, implica uma relação entre o meio e a produção imaginária. O amadurecimento emocional que outrora Davi possuía na vida que levava acompanhado pelas pessoas, no tempo enunciado é outro. Isso se dá, pois o ambiente facilitador atual possibilita à Davi a incorporação das expe- 
riências provenientes de sua criatividade infantil. O personagem responde ao insólito, dessa maneira, sob reações atípicas daquele Davi anterior ao desaparecimento de todas as pessoas.

Ainda a partir de Winnicott (1968), identificamos que o enunciador apresenta um Davi que desencadeia um distúrbio derivado de problemas de adaptabilidade do ambiente. O protagonista não encontra formas de orquestrar as características que o constituíam por sujeito social à complexidade dessa nova sociedade constituída por um único indivíduo: ele. A provisão ambiental, dessa maneira, tem papel relevante no processo de amadurecimento emocional de Davi e, consequentemente, pode estimular o co-enunciador a preencher as lacunas dessa crise comportamental ora validando ora repudiando as ações do protagonista, como podemos observar no recorte abaixo.

\section{Recorte II (BRAS, 2012a, p.12)}

Duas cores cordiais: o vermelho e o azul. Ele acende o isqueiro vermelho e fica observando a chama azul. É uma fada delicada. Linda. Para inúmeras culturas antigas o fogo era a origem e a essência do mundo. Ele recolhe o polegar, o pino que libera o gás volta à posição de descanso, a chama morre. Em sua mão o isqueiro foi promovido a varinha mágica? Ideia ridicula, eu sei. Infantil demais. Mas dê uma pilha de papel e um isqueiro a um homem sem qualidades perceptíveis e, tcharam, ele logo voltará a ser a criança demente e descontrolada que sempre foi.

No recorte II, identificamos uma inscrição possível a um quadro hermenêutico metaficcional do discurso em análise. Trata-se de uma ficção enunciada que implica o diálogo com outras ficções da fantasia ou do fantástico, lidando com o insólito enigmático e mágico. Quando o enunciador recorre à fada-dragão como metáfora para a chama do isqueiro, o discurso estabelece relações com formações discursivas de narrativas fantásticas que recuperam as fadas e os dragões como personagens de um mundo imaginado, governado por magias e feitiços. O enunciador projeta-se, ainda, como personagem da própria ficção que enuncia, ao utilizar novamente do recurso da segunda pessoa, estabelecendo um diálogo com um co-enunciador-personagem: Em sua mão o isqueiro foi promovido a varinha mágica?. A construção de uma relação de diálogo com o co-enunciador nos possibilita compreender que há pelo menos três planos ficcionais no recorte: o plano do Davi sozinho sem nenhuma companhia; o plano das lembranças de Davi de como era sua vida antes de estar só, sob o olhar do enunciador-personagem, uma vez que tudo que o co-enunciador tem contato da vida de Davi antes de todos 
sumirem é fruto das lembranças de Davi sob o filtro do enunciador-personagem; o mundo do enunciador-personagem que em certos momentos parece admitir que toda a vida de Davi é uma ficção imaginada por ele, que também assume uma posição limítrofe entre o ficcional e a função-autor.

O enunciador-personagem também utiliza do subterfúgio da fantasia como estatuto pragmático para envolver o co-enunciador a uma trama de mensagens ocultas que escondem subjetividades relevantes para uma coletividade. Nos enunciados Ele acende o isqueiro vermelho e fica observando a chama azul. É uma fada delicada. Linda. e Em sua mão o isqueiro foi promovido a varinha mágica? Ideia ridícula, eu sei. Infantil demais., o co-enunciador está diante de um enigma insólito, no sentido que é alimentado pela dúvida: Davi imagina as chamas do isqueiro transformarem-se em uma fada delicada ou esta é uma leitura não autorizada do enunciador na condição de narrador-personagem? O enunciador apresenta um juízo de valor sobre aquilo que Davi supostamente imagina, ao observar as chamas do isqueiro: um sujeito infantil, um homem sem qualidades perceptíveis que retorna à condição de criança demente e descontrolada. $\mathrm{O}$ uso de sem qualidades perceptíveis e criança demente e descontrolada para se referir à Davi implica um olhar acusatório do enunciador, que cria um juízo de valor questionável sobre o indivíduo que incendeia a livraria. Nesse sentido, identificamos que o enunciador possibilita ao co-enunciador o movimento de não reduzir as palavras enunciadas apenas a um nível significante, mas construir efeitos de sentido que se iniciam neste plano e estendem-se à uma reestruturação semântica.

O olhar do co-enunciador para os enunciados presentes no recorte II pode ser motivado por uma leitura metaficcional, no sentido de observar o enunciador realizar uma ficção sobre a ficção, incluindo dentro da própria história contada comentários e pistas sobre a maneira como ele identifica tudo aquilo que está narrando. Neste caso, a volta de Davi à condição de criança implica um olhar do enunciador sob a noção de que estar só corrompe a competência cognitiva do indivíduo. Este passa a construir sentido das coisas como uma criança recém-nascida construiria. Recuperando Winnicott (1968), identificamos que o enunciador constrói um Davi sob o referencial cognitivo fruto da solidão essencial. Davi volta a ter uma consciência incipiente de si mesmo enquanto sujeito existente no tempo, prejudicando a capacidade de racionalizar o mundo a sua volta. Nessa perspectiva, o fogo não é para Davi, o que foi para os romanos: essência do mundo ou origem. O que a fada-dragão simboliza é a destruição das estruturas cognitivas de Davi para a emergência de um outro Davi fruto da solidão essencial. Este Davi solitário buscará integração em uma identidade unitária, pois tem a capacidade de perceber o ambiente como algo nem externo nem interno a si. Isso quer dizer que tudo que Davi imagina ser, para Davi de fato é, já que não há o Outro para desmentir ou invalidar as construções de sentido que lança mão sobre 
o mundo a sua volta. No entanto, Davi desconhece que ele é produto da imaginação de um enunciador-personagem que reconhece nele o retrocesso das competências cognitivas e cria juízos morais dessa condição.

Davi está, nesse sentido, sob a influência de uma raiz precoce do desenvolvimento emocional, o que requer uma dependência maior do ambiente que não oferece a ele respostas significativas e racionais. Então, a saída é recorrer ao insólito imaginado, onde fadas-dragão emergem de isqueiros e consomem tudo que é físico em uma livraria. Davi é um Davi despedaçado incapaz de perceber as novas regras do ambiente, já que perdeu todas as características de seu self individual que discriminava o eu de Davi de um não eu: em um mundo sem ninguém, não há parâmetros ou referenciais para o reconhecimento de si mesmo; logo, aquele sujeito que vive em um mundo onde somente ele existe, a sua condição essencial não se desenvolve. Davi está em uma condição de solidão essencial, ao passo que nem mesmo os conhecimentos do mundo anterior o qual ele vivia e desenvolvia seu intelecto não são suficientes para entender o novo mundo o qual ele vive, como podemos observar no recorte abaixo:

Recorte III (BRAS, 2012a, p.15)

Mas esse tipo de conhecimento não é suficiente pra fazer desse homem um homem feliz. Não, non, nein, niet, extintas salas comerciais, poliglotas salas comerciais da grande avenida! Esse tipo de conhecimento tão luminoso, tão repetido nos livros incendiados, não é capaz de salvar esse pobre coitado - o último aprendiz de feiticeiro - do vazio e da sombra.

Os enunciados apresentados no recorte III, quando submetidos a um quadro hermenêutico metaficcional, concentra uma clareza enganosa que implica um esforço do co-enunciador para desdobrá-lo a partir de duas ficções postas. Em um primeiro plano, temos o enunciador apresentando um mundo onde Davi vive sozinho e os conhecimentos construídos já não servem de mais nada, posto que é necessário construir um novo santuário da felicidade para direcionar as subjetividades da personagem. O uso de enunciados como não, non, nein, niet, é uma forma engenhosa do enunciador observar que conhecimentos globais do mundo povoado já não servem para direcionar Davi como antes serviu.

Pouco a pouco, os enunciados podem convidar o co-enunciador a derivar sentidos ocultos, buscando o ponto onde a clareza da trajetória de Davi se obscurece, a fim de apontar o enigma em potencial para um outro nível de realidade ficcional. Isso se dá em um segundo plano, em que não podemos ignorar o cons- 
tante diálogo entre o enunciador-personagem e o co-enunciador, estabelecido em diversos instantes ao longo da obra. Davi é reconhecido por personagem pelo enunciador que rompe com a cenografia ficcional para estabelecer dicas ao co-enunciador de como aquela ficção criada caminha. Os conhecimentos das extintas salas comerciais, da grande avenida, a qual é uma referência à Avenida Paulista em São Paulo, também são tomadas como insuficientes para o enunciador na construção do mundo solitário de Davi. A clareza enganosa que se estabelece no recorte III implica a noção de que para o enunciador, os conhecimentos provenientes da luz das salas comerciais, dos grandes escritórios, da pluralidade da zona comercial paulistana tradicionalmente centralizada na região da Avenida Paulista são insuficientes para fortalecer Davi em uma caminhada existencial, subjetiva, em busca do encontro de sua identificação com um mundo que ele passa a não reconhecer. Embora estes sejam os mantras tão almejados por boa parte da lógica do mercado financeiro, das startups e de toda a economia global, são conhecimentos insuficientes para auxiliar o enunciador a apontar uma saída à Davi e para Davi encontrar sua própria identidade com o mundo que o cerca.

O quadro hermenêutico da metaficção, nesse sentido, garante que a transgressão enunciada do mundo solitário de Davi seja apenas aparente. A metaficção define os contornos da natureza do sentido oculto do discurso literário que se situa em um enunciar pelas fronteiras. O enunciador estabelece diálogo direto com o co-enunciador projetando em Davi o peso de todo um mundo que não faz mais parte de seu universo ficcional. O universo ficcional de Davi é o mundo solitário, sem ninguém. O universo ficcional do enunciador está implicado nesse universo de Davi e pode ser tomado pelas mesmas regras dos referenciais que o co-enunciador possui para a construção de sentidos dos enunciados apresentados. Davi é, dessa maneira, uma marionete semelhante àquela utilizada por Cervantes para ludibriar Dom Quixote. No entanto, quem está sob o feitiço das cordas não é o cavaleiro andante, mas o próprio co-enunciador que percorre e sente junto de Davi os sintomas e as consequências da solidão. O recorte III, nesse sentido, concentra-se em um enigma e pouco a pouco o revela ao co-enunciador que passa e compreender o jogo metaficcional que se encontra.

A metaficção presente no recorte III pode ser identificada também pela relação do co-enunciador com o heterocosmo que não permite que a distância entre o co-enunciador e Davi fique tão clara. Na medida que o co-enunciador toma contato com os enunciados, ele experiencia as regras de um mundo que considera ficcional. Paradoxalmente, por sua vez, os enunciados do universo do Davi exigem a participação direta do co-enunciador, bem como seu envolvimento intelec- 
tual, imaginativo e afetivo na co-criação dos sentidos entorno da potencia de extinção das salas comerciais, dos poliglotas presentes nestas salas, do que eles falam, de qual realidade eles se cercam, quais suas subjetividades. $\mathrm{O}$ paradoxo o qual o co-enunciador está inserido implica, na metaficção, uma atração bilateral: há a reflexão entorno das condições de Davi e sua solidão, como também há uma projeção para o exterior, orientado ao co-enunciador, que pode se questionar se estaria ele preparado subjetivamente para uma experiência de solidão existencial avassaladora pela qual passa Davi.

Identificamos que, para o enunciador, Davi está sob os efeitos de uma solidão essencial. A partir de Winnicott (1968), compreendemos que Davi está sob a tensão entre o não-ser e o ser. Isso quer dizer que, ao longo da existência apresentada pelo enunciador, Davi se encontra comprometido com a dialética daquilo que ele foi e daquilo que ele não sabe mais o que será. Trata-se, em outras palavras, de uma dinâmica de não-integração à integração em um mundo onde só ele existe. O problema enunciado é que os direcionamentos ambientais disponíveis são confusos e não permitem a reintegração de Davi àquele meio, senão pelo gatilho de um sistema de coerções infantil: esse pobre coitado - o último aprendiz de feiticeiro. Por o universo criado estar em um possível controle do enunciador-personagem, sob um direcionamento metaficcional, o co-enunciador compreende que aquela falta de conexão de Davi com os direcionamentos ambientais o levam cada vez mais ao vazio e à sombra.

O enunciador, nesse sentido, apresenta um Davi incapaz de existir sozinho, posto que a natureza criada para ele não é a de um monge que desenvolveu sua capacidade de equilíbrio consigo mesmo, mas de um sujeito médio, sem nenhuma habilidade ou característica especial para esse mundo solitário. A própria natureza lacunosa de Davi lhe impõe a necessidade de um outro que lhe cuide, lhe sustente, lhe proteja. Tudo isso implica sua constituição e sua identidade. Davi não consegue, nesse sentido, continuar a ser, já que as intrusões ambientais o traumatizam, interrompem sua continuidade. A solidão essencial parte do pressuposto da não comunicação, do ser isolado, desconhecido, em uma realidade pela qual ele não consegue encontrar razão semântica. Isso conduz Davi a utilizar o recurso dos gestos espontâneos, da criatividade originária e imatura, e ele só o faz quando não reconhece o ambiente como tal, não consegue mais racionalizá-lo. Por Davi ser uma vida criada pelo enunciador-personagem, e o mesmo estabelecer contato direto com o co-enunciador, os mesmos efeitos são reiterados pelo co-enunciador em uma perspectiva metaficcional. 


\section{CONSIDERAÇÕES FINAIS}

Constatamos, por fim, que a constituição de um quadro hermenêutico enunciativo-discursivo pode ser tomada como uma diretriz produtiva para o desenvolvimento de pesquisas em Análise do Discurso. O quadro hermenêutico implica o delinear de regras para as negociações dos efeitos de sentido em um discurso literário e é pela cenografia que o analista pode encontrar as pistas para esta configuração.

Em nossa pesquisa, selecionamos a metaficção como direcionamento para delinear as regras de nosso quadro hermenêutico. Tomamos a ficção científica como um arcabouço de discursos literários que possuem o novum por gatilho para a constituição de perspectivas ficcionais em abismo. Cabe ao co-enunciador desvelar os nós desses novelos ficcionais entramados na cenografia, estabelecendo os nexos necessários para uma dupla ficção: a ficção concebida na enunciação, ligada a uma outra ficção enunciada em um tempo e em um espaço outro, concomitantes.

Destacamos, por fim, que o novum presente em nossa amostra pode ser problematizado sob o auxílio de formações discursivas da Psicologia Clínica. A condição de estar só, urgente no desenvolvimento cognitivo das fases iniciais da vida de um sujeito social, é desenvolvida, no discurso literário em análise, como um acontecimento insólito que incide no desaparecimento de todas as pessoas do planeta, com exceção de Davi. O insólito, assim, pode ser fundamentado, ainda que não o esclareça, pelas noções de solidão essencial, a partir de Batista (2017). Compreendemos, contudo, que esta não é uma pesquisa que fecha discussões, mas pretende abri-las, a fim de potencializar o diálogo entre Análise do Discurso e Crítica Literária.

\section{REFERÊNCIAS}

BATISTA, J. L.. A capacidade de estar só: a perspectiva psicanalítica de D.W. Winnicott. Dissertação de Mestrado em Psicologia Clínica. PUC-SP. São Paulo, 2017.

BERNARDO, Gustavo. O livro da metaficção. Rio de Janeiro: Tinta Negra Bazar Editorial, 2010.

BRAS, Luiz. Sozinho no deserto extremo. São Paulo: Prumo, 2012a.

BRAS, Luiz. Convite ao mainstream. In.: Jornal Rascunho. Fev, 2012b.

HUTCHEON, Linda. Narcissistic Narrative: the metafictional paradox. New York: Methuen, .1984.

MAINGUENEAU, Dominique. Discurso literário. São Paulo: Contexto, 2006. 
MIZRAHI, B. G.; GARCIA, C. A.. A capacidade de estar só: um contraponto winnicottiano ao ideal contemporâneo de autonomia absoluta. In.: Psicologia em Revista. Belo Horizonte. v. 13, n.2. dez., 2007.

MATANGRANO, Bruno; TAVARES, Enéias Fantástico brasileiro: o insólito literário do romantismo ao fanatismo. Curitiba: Arte \& Letra, 2018.

NAVAS, Diana. Narcisismo discursivo e metaficção: Antonio Lobo Antunes e a revolução do romance. São Paulo: Scortecci, 2009.

ROBERTS, Adam. A verdadeira história da ficção científica: do preconceito à conquista das massas. Trad. Mário Molina. São Paulo: Seoman, 2018.

WINNICOTT, D. W. A capacidade para estar-só. In: O ambiente e os processos de maturação. Porto Alegre: Artes Médicas. p. 31-37,1998. (Originalmente publicado em 1958). 